\title{
2 Impact of the COVID-19 pandemic on the differentiation of selected macroeconomic variables characterizing the EU economies over a short period
}

\author{
Monika Bolinska, Rafat Wista, and \\ Michat Wtodarczyk
}

\subsection{Introduction}

The COVID-19 pandemic cast a long shadow over the world's economies in 2020 and the economic outlook in 2021 is very uncertain (OECD, 2020). The scale and dynamics of the spread of the COVID-19 pandemic, caused by a coronavirus, entailed serious disturbances in social and economic life. The 2020+ pandemic is not only the most serious global health crisis since the Spanish flu of 1918 but also one of the most economically expensive pandemics on a global scale. The World Bank stated that the COVID-19 pandemic has plunged the global economy into its deepest recession since World War II. Per capita incomes are expected to decline in about $90 \%$ of countries in 2020, the largest fraction since 1870 (Dieppe, 2020).

Looking at the four quarters of 2020, it is clear that the restrictions on social and economic life, imposed in line with various rules, had a stronger effect on the value of aggregate demand (and due to the Keynesian multiplier effect, on the volume of production) than on the supply aspect of the economy. Consumer expenditures in the household sector represent the most important component of domestic demand and account for about $55 \%$ of the situation of European economies (the dynamics of changes in the gross domestic product (GDP) and its structure, labor market condition, and indirectly the condition of public finance and international competitive advantage, etc.). Considering an additional decrease in the volume of exports and gross fixed capital formation (that is aimed to strengthen the economy's manufacturing potential), a grim picture of the European economies in 2020 emerges.

The International Monetary Fund (IMF) argues that most economies will suffer a durable loss in their manufacturing potential due to the 2020+ pandemic, and this will decelerate growth in the following years. It will take time for the labor market to recover to its pre-2020 condition, as investments will be postponed due to uncertainty, and unemployment and loss 
of schooling will cause erosion in human and social capital (Dieppe, 2020). The crisis caused by the pandemic would be more severe if it were not for rapid counteraction by governments and central banks that supported enterprises in maintaining their financial liquidity and to a significant extent upheld employment and household income (IMF, 2020). The European Union has responded to the outbreak of COVID-19 and its consequences by adopting a wide range of measures in many areas: public health, society, economy, etc. ${ }^{1}$

The COVID-19 pandemic has generated a very large volume of research related to the basic biology of coronavirus infection, its detection, treatment and evolution, ${ }^{2}$ but also related to its economic consequences. ${ }^{3}$ In terms of economics, most of the research is focused on aggregate macroeconomic effects (Atkeson, 2020; Baumeister, Guérin, 2020; Ludvigson, Ma \& Ng, 2020), labor markets (Forsythe, Kahn, Lange \& Wiczer, 2020), costs of the pandemic and its containment (Brock, Xepapadeas, 2020; Lik Ng, 2020).

This chapter aims to assess the impact of the COVID-19 pandemic on the differentiation of selected macroeconomic variables in the European Union (EU) economies. The study examined 27 European countries that were members of the European Union at the time of the announcement of the pandemic by the World Health Organization (WHO) on March 11, 2020. The analysis did not include the United Kingdom, which left the European Union on January 31, 2020. The following macro-indicators were analyzed and assessed: gross domestic product per capita, the unemployment rate, gross fixed capital formation per capita, exports of goods and services per capita, and imports of goods and services per capita. The research project included both a long (2006-2020) and a short (Q2 of 2020 vs. Q2 of 2019) period.

The macro-indicators are discussed in this analysis using a dynamic approach (in time) and a spatial approach (the level of countries). The economies of the EU member states are classified in quintile groups with the lowest (five countries), low (five), average (six), high (five) and the highest (five) values of the analyzed variables. The groups have different compositions in the analysis of unemployment because the changes in unemployment rates in those countries were insignificant between Q2 of 2019 and Q2 of 2020.

Short-term comparative analyses cover the second quarters of 2019 and 2020 , the period of the sharpest decreases in the discussed macroeconomic

1 European Parliament's EU response (https://www.europarl.europa.eu/news/en/headlines/priorities/eu-response-to-coronavirus); European Commission (https://ec.europa.eu/info/livework-travel-eu/coronavirus-response_en).

2 See, for example, the websites at https://www.nature.com/collections/hajgidghjb.

3 See: https://www.nber.org/wp_covid19.html or https://covid-19.iza.org/publications/.

4 Both the analyzed period and the selected macroeconomic variables were determined by the availability of statistics on the EUROSTAT website: https://ec.europa.eu/eurostat/data/ database. 


\section{Monika Bolińska et al.}

aggregates. Slovakia is classified in a separate group with a 0 value on the maps due to the absence of statistics for that country (except the unemployment map). This chapter contains a cluster analysis employing Ward's method with Euclidean distance, and a study into variations of selected macroeconomic characteristics in quarterly periods in the years 2006-2020.

\subsection{Gross domestic product per capita}

If we assume that GDP per capita gives a synthetic, general, albeit imperfect image of the level of wealth of an average citizen of a country and build a tree of clusters of similarities and differences in this macro-indicator in the group of 27 member states of the European Union (Figure 2.1), the general conclusions discussed below can be drawn. The highest similarities in this macroeconomic variable in the period 2006-2020 (considering quarterly values) were characteristic of the following country pairs: Belgium and Finland, Denmark and the Netherlands, Cyprus and Slovenia, Greece and Latvia, Latvia and Lithuania, Croatia and Poland, and Germany and France. An analysis of clusters of EU countries also led to the distinction

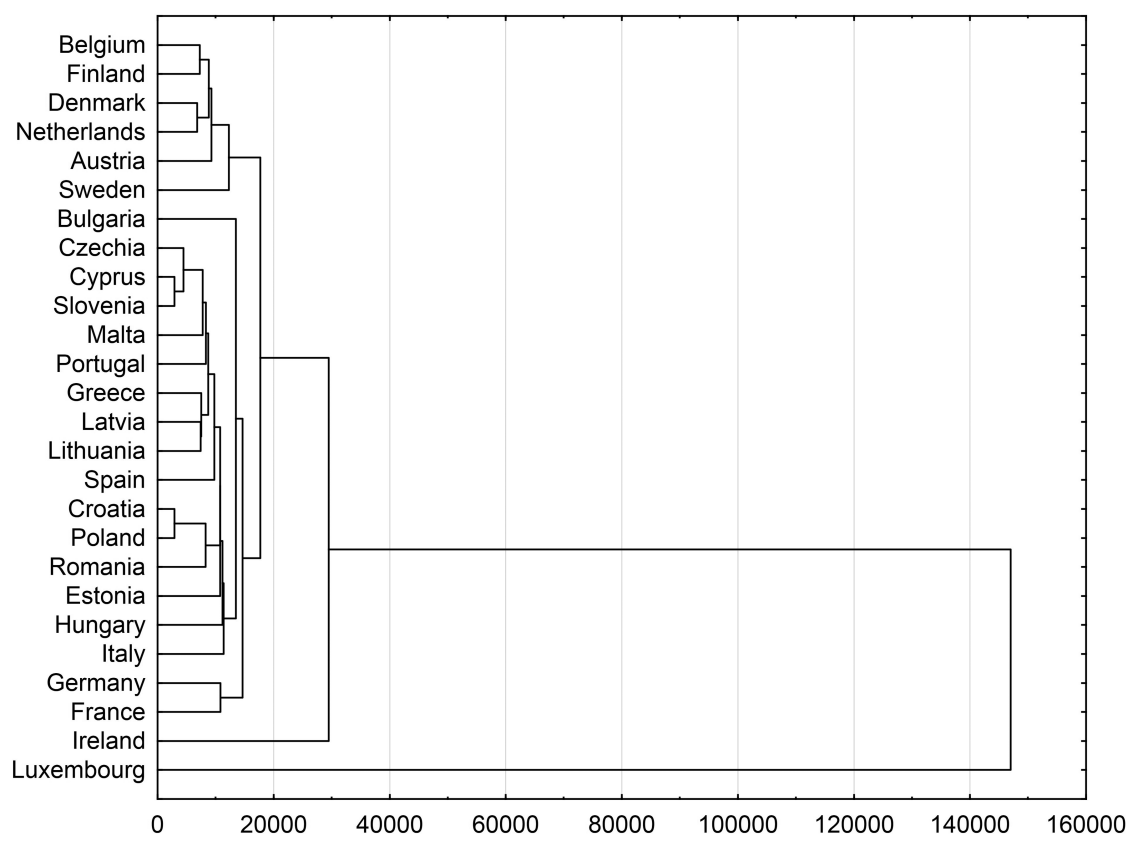

Figure 2.1 A dendrogram of GDP per capita in the member states of the EU (20062020, Euclidean distance). Source: own calculation based on https://ec. europa.eu/eurostat/data/database. 
of three main similarity clusters. The first cluster is formed by Belgium, Finland, Germany, the Netherlands, Austria and Sweden. The second cluster includes the Czech Republic, Cyprus, Slovenia, Malta, Portugal, Greece, Latvia, Lithuania and Spain. The last cluster is formed by Croatia, Poland, Romania, Estonia, Hungary and Italy. Luxembourg and Ireland with their high values of GDP per capita clearly stand out from the other countries.

Between the years 2006 and 2020, the lowest values of GDP per capita were recorded in Bulgaria (EUR 1,338.78), Croatia (EUR 3,995.16), Poland (EUR 4,131.15), Romania (EUR 4,398.21) and Lithuania (EUR $5,643.06)$. The highest values of the analyzed variable were recorded in Luxembourg (EUR 35,117.87), one of the largest global financial centers. The group of countries with the highest values of GDP per capita included: the Netherlands (EUR 15,571.39), Denmark (EUR 15,606.95), Sweden (EUR 16,052.14) and Austria (EUR 16,316.64).

The analysis of long-term similarities and differences is juxtaposed below with an analysis of a very short period of the sharpest decrease in the values of discussed macroeconomic aggregates since the end of World War II, i.e. in Q2 of 2020.

Maps 2.1(a) and 2.1(b) show the value of GDP per capita in Q2 of 2019 and Q2 of 2020. Over the analyzed period, the greatest falls in GDP per capita occurred in the economies of Luxembourg (a decrease by EUR 3,048.36 in Q2 of 2020 vs. Q2 of 2019), Austria (EUR 2,271.61), the Netherlands (EUR 2,027.30), Belgium (EUR 1,902.88), France (EUR 1,869.73), Spain (EUR 1,589.29), Sweden (EUR 1,556. 00) and Malta (EUR 1,504.74). These countries are classified in the groups with average, high and the highest values of the discussed variable.

The slightest falls of GDP per capita were recorded in Bulgaria (a decrease by EUR 367.08 in Q2 of 2020 vs. Q2 of 2019), Lithuania (EUR 627.21), Croatia (EUR 677.73), Portugal (EUR 700.33), Romania (EUR 710.99), Poland (EUR 711.31), Latvia (EUR 771.12), Greece (EUR 815.90) and Estonia (EUR 905.01). These states constituted the groups with the lowest, low and average values of GDP per capita.

Eight countries changed their positions in the ranking of average wealth between Q2 of 2019 and Q2 of 2020. Austria, Hungary, Spain, Cyprus, Estonia, Finland and Poland changed their positions by one within the quintile groups they belong to until the end of 2019. The Czech Republic dropped to the quintile group with lower values of GDP per capita. Estonia entered in the second quarter of 2020 the group with higher values of the analyzed variable, compared to the corresponding period in the preceding year.

The depth of decreases in GDP (and consequently GDP per capita) in the second quarter of 2020 was unprecedented in the post-war history of the member states of the former European Communities and the current European Union. The greatest falls in GDP were recorded in Spain $(-21.5 \%$ in Q2 of 2020 vs. Q2 of 2019$)$, France $(-18.9 \%)$, Italy $(-18.0 \%)$, 

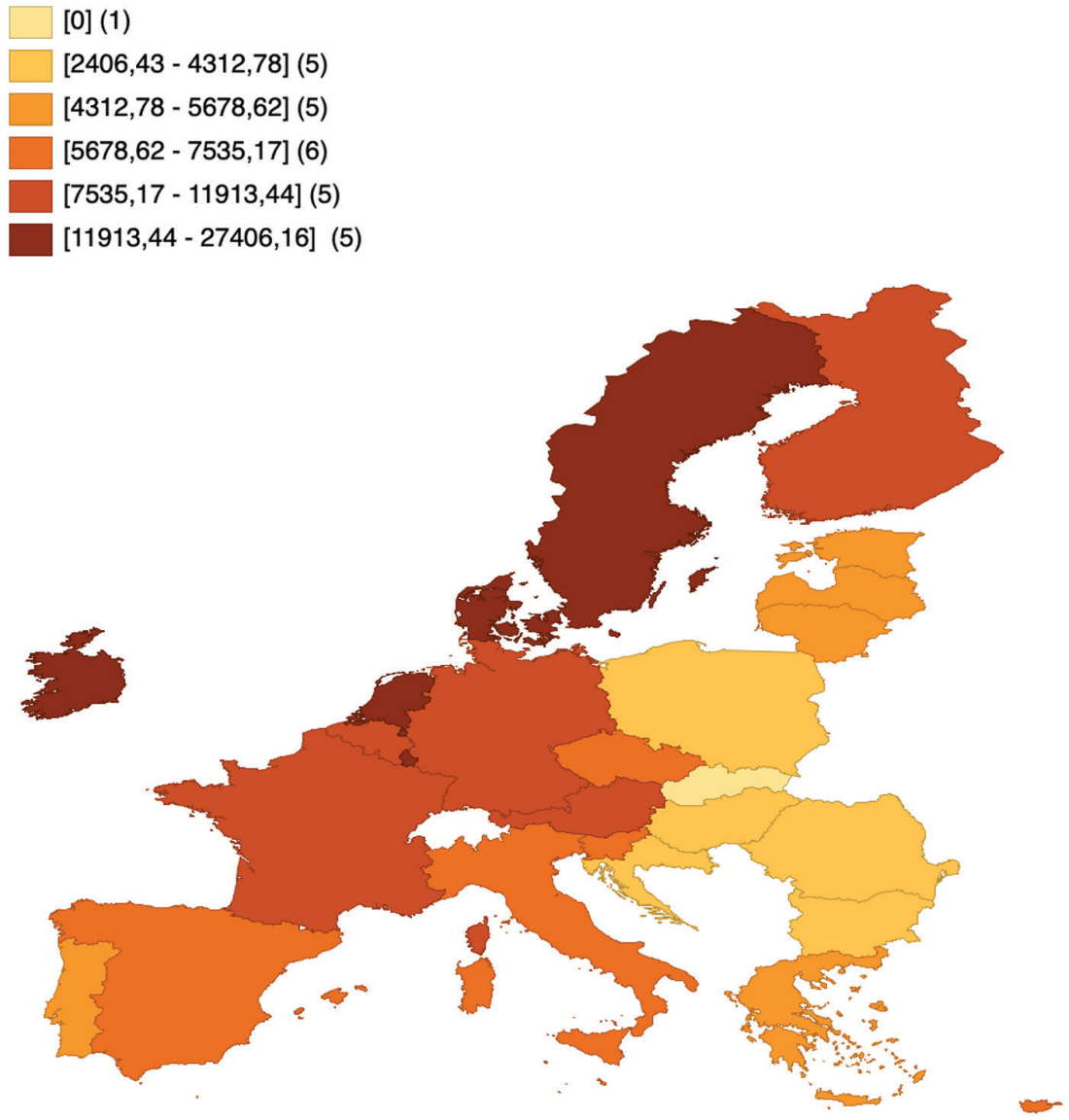

Map 2.1a Spatial differentiation of GDP per capita in the second quarters of 2019 in the member states of the European Union (in EUR, constant prices from Q2 of 2020). Source: own calculation based on https://ec.europa.eu/ eurostat/data/database.

Malta, Portugal, Croatia, Greece, Austria, Belgium, Hungary (decreases by $-16.7 \%$ to $-13.5 \%$ ); relatively slighter decreases were recorded in Lithuania $(-4.6 \%)$ and Ireland $(-3.5 \%)$. The third quarter of 2020 still saw a downward trend in GDP values, except Ireland (8.1\% growth in Q3 of 2020 vs. Q3 of 2019). Despite a decrease in GDP by $1.8 \%$ in the third quarter, Poland increased its proportion of EU GDP from 3.82 to 3.94 percent, i.e. by 0.12 percentage points. Proportions of EU GDP increased by higher percentages only in the case of Ireland, the Netherlands and Sweden. 

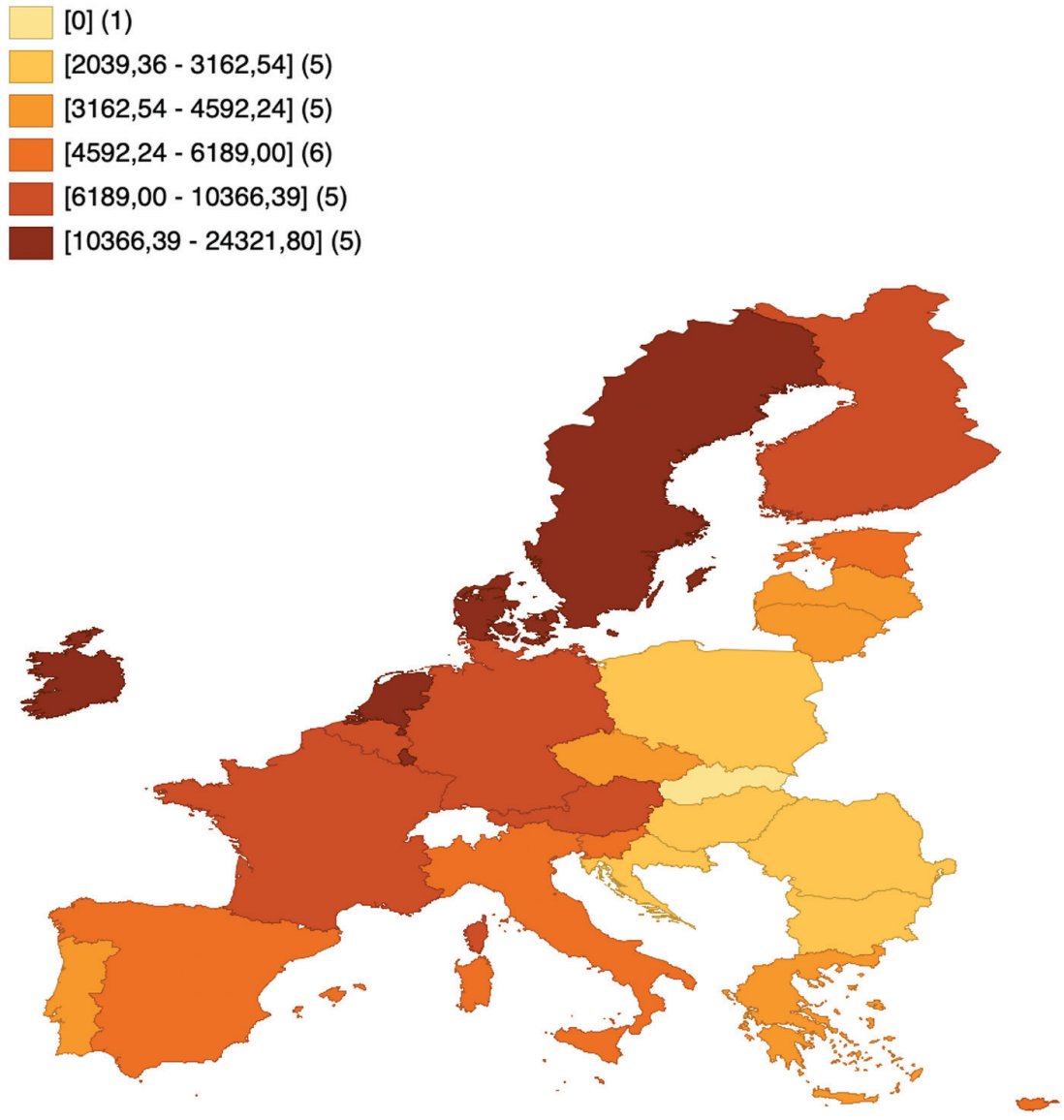

Map 2.1b Spatial differentiation of GDP per capita in the second quarters of 2020 in the member states of the European Union (in EUR, constant prices from Q2 of 2020). Source: own calculation based on https://ec.europa.eu/ eurostat/data/database.

\subsection{Unemployment}

The unemployment rate is correlated with the curve of the economic situation, both at the level of member states and that of the entire EU economy.

Figure 2.2 shows the changes in the unemployment rate in the European Union countries, from this figure we can conclude the following statements. A decrease in the unemployment rate was observed between the first quarter of 2006 and the corresponding quarter of 2008 due to a favorable economic situation in the European Union. The decrease in the unemployment rate 
26 Monika Bolińska et al.

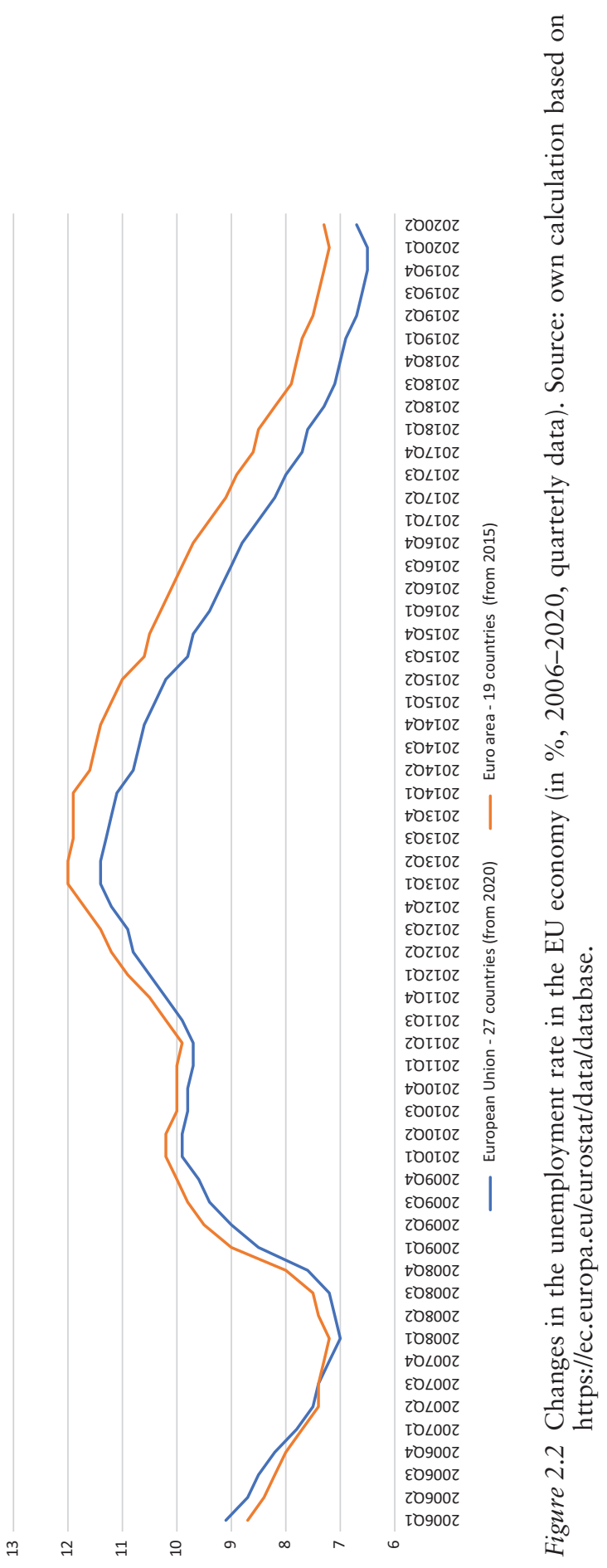


in that time interval amounted to more than $1 \%$. The unemployment rate grew in the following quarters (from the second quarter of 2008 to the third quarter of 2013). This unfavorable trend was caused by a global shock (the crisis of 2008+), exogenous in its nature to the EU economy. The greatest increase in the unemployment rate was recorded between the last quarter of 2008 and the first quarter of 2009. The average increase in the rate of unemployment between Q2 of 2008 and Q3 of 2013 amounted to $2.4 \%$. In the following periods, the unemployment rate dropped, by $0.1 \%$ on average period-over-period, until the second quarter of 2020, when unemployment grew by 0.1 percentage points compared to the first quarter of that year. The increase in the unemployment rate resulted from the economic restrictions imposed by European economies in response to the spread of the SARS-CoV-2 virus. Figure 2.3 represents a clustering tree of similarities and differences in unemployment rates in the member states of the $\mathrm{EU}$ in the years 2006-2020 (including the second quarter of 2020).

The dendrogram identifies the following pairs of similar countries: Belgium and Finland, Malta and Romania, Luxembourg and Austria, Hungary and Poland, Ireland and Lithuania, Croatia and Portugal, and Greece and Spain. An analysis of the clustering tree demonstrates the following similarity clusters. The first cluster is formed by Croatia, Slovakia and

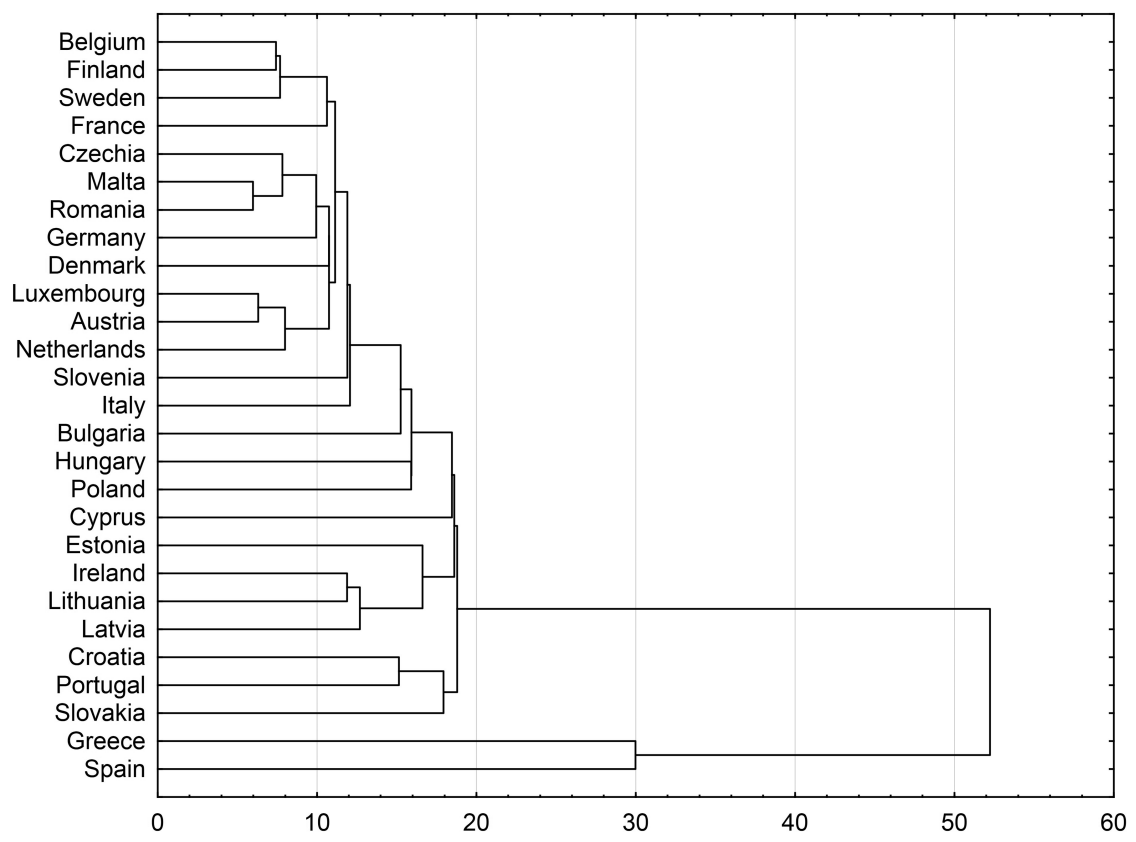

Figure 2.3 A dendrogram of unemployment rates in the EU (2006-2020, Euclidean distance). Source: own calculation based on https://ec.europa.eu/eurostat/ data/database. 
Portugal, where the average unemployment rate amounted to about $11 \%$ in the analyzed time interval. Another cluster is formed by three states located in the north-eastern part of Europe: Lithuania, Latvia and Estonia, plus Ireland. The third cluster includes Belgium, Finland, Sweden and France, where the average unemployment rate amounted to about $8 \%$. The last and largest cluster is formed by the Czech Republic, Malta, Denmark, Romania, Germany, Luxembourg, Austria and the Netherlands.

The highest average unemployment rates in the years 2006-2020 occurred in Greece (17.85\%), Spain (17.81\%), Croatia (12.00\%), Slovakia $(11.06 \%)$ and Latvia $(10.86 \%)$. The lowest average unemployment rates were recorded in Iceland (4.43\%), Austria $(5.12 \%)$, the Netherlands $(5.13 \%)$, the Czech Republic (5.16\%) and Luxembourg (5.38\%).

The analysis of long-term similarities and differences is juxtaposed below with an analysis of short-term responses of unemployment rates to the circumstances between Q2 of 2019 and Q2 of 2020. Maps 2.2(a) and 2.2(b) represent spatially differentiated rates of registered unemployment in the 27 member states of the EU in the second quarters of 2019 and 2020.

The lowest unemployment rates both in 2019 and in 2020 were recorded in the central area of the European Union. Twenty-one states changed their positions in the ranking between Q2 of 2019 and Q2 of 2020: 11 states dropped in the ranking and 10 were ranked higher. The largest fall affected Lithuania; the country dropped by eight positions in the ranking of registered unemployment rates. Also, Estonia dropped by six positions; the countries that dropped by five positions in the ranking were Latvia, Bulgaria and Sweden. The group of states that went down also includes Romania (down four positions), Austria (down two positions), and Finland, Germany, Hungary and the Netherlands (down one position).

In contrast, Portugal advanced by seven positions, Belgium advanced by six positions, and Croatia, Ireland and Cyprus each advanced by five positions. The group of states that reached higher positions also included France (by four positions), Italy (by three positions), Poland (by two positions), and Malta and Denmark (by one position).

Both a decrease and an increase in the unemployment rate was observed between the discussed quarters. The unemployment rate fell only in seven countries. Between Q2 of 2019 and Q2 of 2020, the unemployment rate fell in Italy (2.1 percentage points), France (1.3 percentage points), Portugal (0.7 percentage points), Belgium (0.5 percentage points), Greece (0.3 percentage points) and Poland and Ireland (0.2 percentage points each). The unemployment rate grew in 20 states in the analyzed time interval. The largest increases (exceeding 1.5 percentage points) were recorded in Bulgaria (1.5 percentage points), Romania (1.6 percentage points), Latvia (1.7 percentage points), Estonia (1.9 percentage points), Sweden (1.9 percentage points) and Lithuania (2.4 percentage points).

This variety of responses of labor markets to the supply and demand shock in Q2 of 2020 can be interpreted from various perspectives. The causes of such diversity should be sought in the varying scenarios of the 


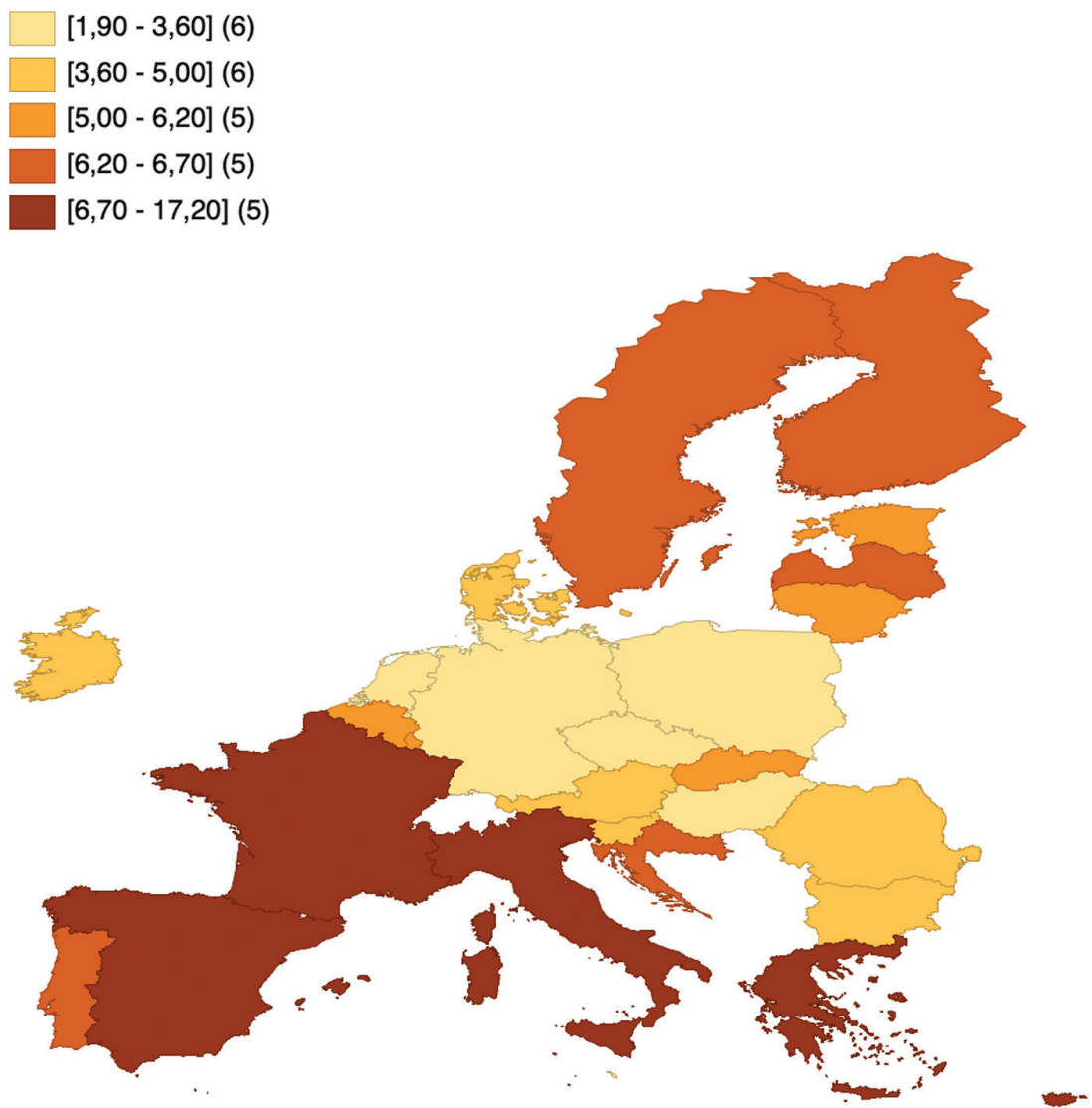

Map 2.2a Unemployment in the second quarter of 2019 in the EU countries (in \%). Source: own calculation based on https:/ec.europa.eu/eurostat/data/ database.

implementation of lockdown measures. First, a rapid introduction of lockdown measures has a stronger effect on accumulated social and economic activity than continual increases and decreases in the severity of restrictions on that activity. Second, a scenario of strong rapid lockdown has the most serious adverse consequences for the economy, both in terms of the sharpness of decrease in production, the time of staying on the relatively lowest growth path, and the expected accumulated decrease in production. Similar conclusions concern the changes in social utility and labor market.

The unemployment rate in Poland amounted in October 2020 to $3.5 \%$, as per the EU standard methods, while in the Czech Republic it reached $2.9 \%$ - the best result in this category in the European Union. The number of unemployed in the European Union by the end of October 2020 amounted to 13.8 million. This was 1.7 million (13.9\%) more than in 
$[2,30-4,60](6)$

$[4,60-5,40](5)$

$[5,40-6,60](5)$

$[6,60-7,90](6)$

$[7,90-16,90](5)$

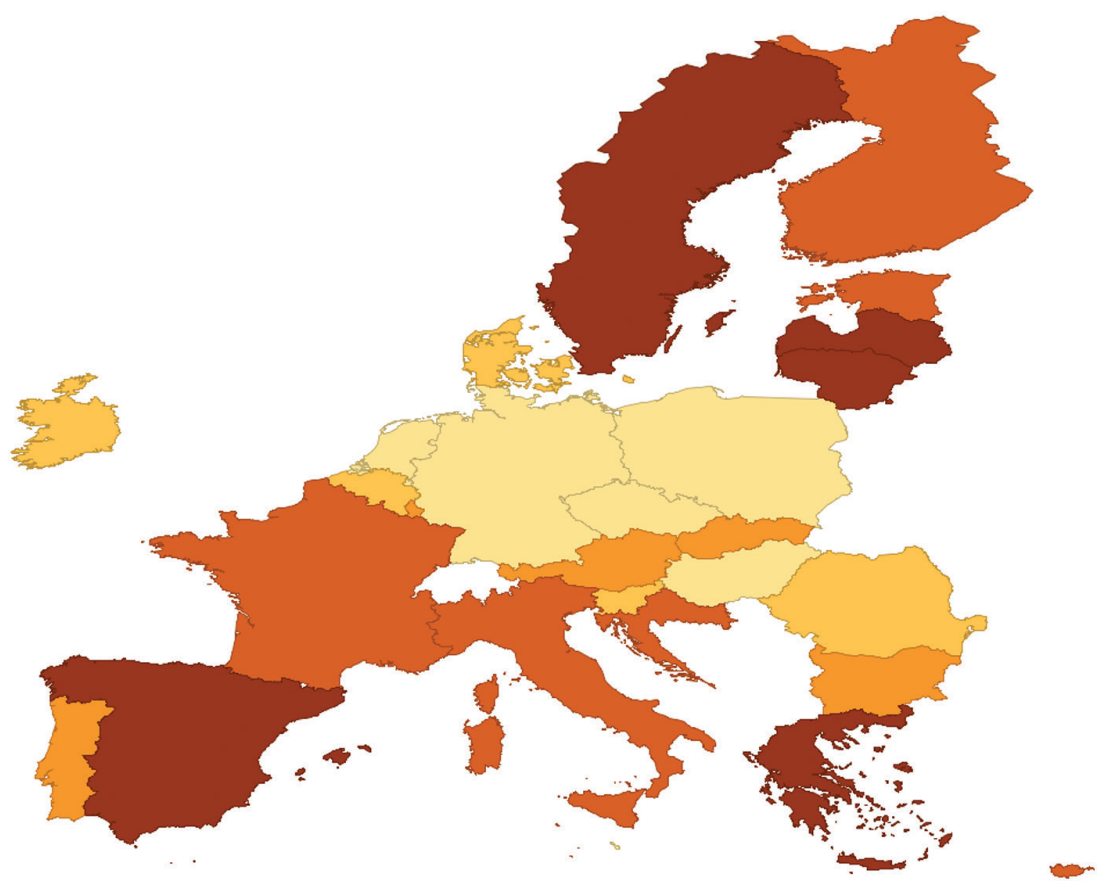

Map 2.2b Unemployment in the second quarter of 2020 in the EU countries (in \%). Source: own calculation based on https://ec.europa.eu/eurostat/data/ database.

2019. The largest increases in the numbers of unemployed were recorded in Germany and Spain.

Employment rose in Q3 of 2020 in Poland (by $0.5 \%$ ) and Malta (by 2.4\%). In the remaining countries of the European Union (except Luxembourg), a continued decrease in the employment rate was observed. Employment in the EU economy dropped by $2 \%$ year-over-year, by 4.3 million people in total.

\subsection{Gross fixed capital formation per capita}

Investing activities of business entities have a direct effect on global demand, production volume, employment and capital accumulation. 
On the basis of Figure 2.4 we can conclude that the gross fixed capital formation in the EU economy as a whole, considered in quarterly periods in the years 2006-2020, underwent three distinct processes. The gross fixed capital formation rose in the European Union until the first quarter of 2008 but began to dramatically drop in the advent of a financial crisis that in the following years evolved into an economic crisis. The EU member states reduced the value of gross fixed capital formation by $0.65 \%$ per annum in the years 2008-2015.

The highest gross fixed capital formation was recorded in the fourth quarter of $2007(23.6 \%)$ and that value was not reached until the second quarter of 2020. The lowest value was recorded in the first quarter of 2015 $(19.6 \%)$. The value of expenditures on gross fixed capital formation bought or produced in the EU economy has significantly fluctuated since 2015 . The greatest fall (by 1.1 percentage points) of gross fixed capital formation was recorded both between the second and third quarters of 2019 and between the first and second quarters of 2020. The average decrease of the analyzed variable between the first quarter of 2006 and the last quarter of 2020 amounted to $0.09 \%$ per annum.

The above general picture of fluctuations in the gross fixed capital formation is supplemented by an analysis of clusters shown in Figure 2.5. In the clustering tree, six pairs of national economies similar in their gross fixed capital formation can be distinguished. The pairs of similar countries comprise Belgium and Finland, Germany and France, Croatia and Poland, Greece and Romania, the Czech Republic and Italy, and Hungary and Slovenia. Four clusters can be distinguished in the 26 analyzed economies (excluding Slovakia). The first includes Belgium, Finland, Austria, Denmark, the Netherlands and Sweden - the analyzed variable assumed on average the highest values in those states. Another cluster is formed by the states with the lowest average value of gross expenditures on gross fixed capital formation in the EU: Bulgaria, Croatia, Poland and Portugal. The third, smallest cluster is formed by Greece, Romania and Lithuania.

The last cluster is formed by the Czech Republic, Italy, Spain, Hungary, Slovenia and Cyprus; these economies (except Cyprus) displayed the same trend in the value of capital expenditures in the analyzed period. Luxembourg is characterized by significantly greater values of the discussed macroeconomic variable (like in the case of GDP). This country clearly stands out from the other member states. The highest average values of per-capita gross expenditures on property and plant equipment in the years 2006-2020 were observed in Luxembourg (EUR 6,486.09), Ireland (EUR 3,904.46), Sweden (EUR 3,793.09), Austria (EUR 3,738.34), Belgium (EUR 3,410.30) and Finland (EUR 3,298.32). The lowest average values of the discussed variable occurred in Bulgaria (EUR 544.91), Poland (EUR 825.60), Croatia (EUR 907.67), Greece (EUR 1,030.93) and Portugal (EUR 1,114.27).

Maps 2.3(a) and 2.3(b) depict the spatial differentiation of gross fixed capital formation in Q2 of 2019 and Q2 of 2020. Sixteen states changed 
32 Monika Bolińska et al.

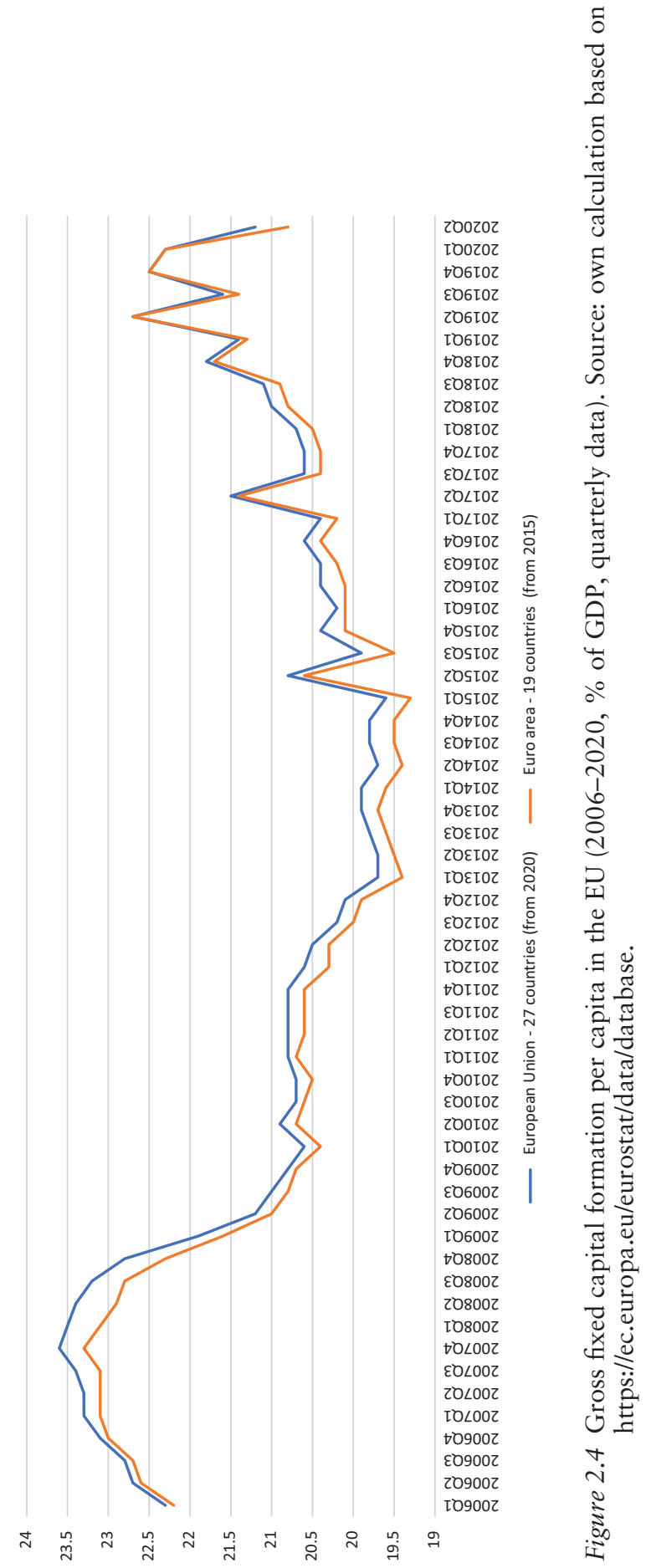




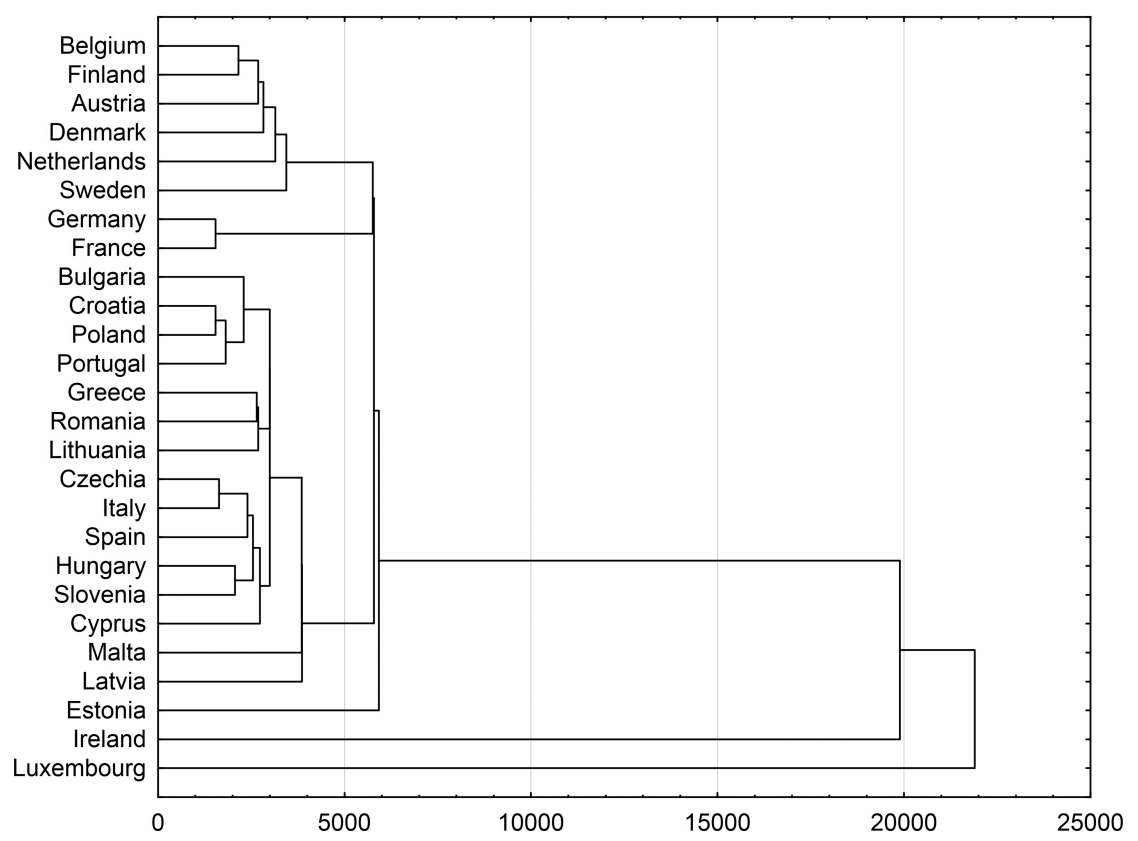

Figure 2.5 A dendrogram of gross fixed capital formation in the EU (2006-2020, Euclidean distance). Source: own calculation based on https://ec.europa .eu/eurostat/data/database.

their positions in the ranking of quintile groups in the analyzed period, due to their reductions in expenditures on gross fixed capital formation bought or produced. The group of countries that reduced their gross fixed capital formation between the analyzed periods included Austria, Belgium, Cyprus, Estonia, Poland and Sweden. The greatest fall, by six positions, affected Cyprus. Additionally, Cyprus and Austria fell to lower quintile groups. Croatia, the Czech Republic, Denmark, Finland, Germany, Hungary, Malta, Portugal, Slovenia and Spain rose in the ranking but remained in their quintile groups. A significant rise was experienced by Portugal (by 3 positions). In the group of ten countries that rose in the ranking, two (Finland and Slovenia) were reclassified in higher quintile groups.

All of the 26 analyzed economies (excluding Slovakia) recorded a general reduction in the per-capita expenditures on gross fixed capital formation. The greatest decreases took place in Ireland (a reduction by EUR 9,150.12 in Q2 of 2020 compared to Q2 of 2019), and Luxembourg (EUR 1,074.45). Significant declines were observed in Cyprus (EUR 663.18), Belgium (EUR 631.57) and France (EUR 566.94). The slightest falls (below EUR 100) were observed in Denmark (EUR 96.50), Romania (EUR 90.07), Portugal (EUR 79.65), Bulgaria (EUR 61.42) and Greece (EUR 40.04). 

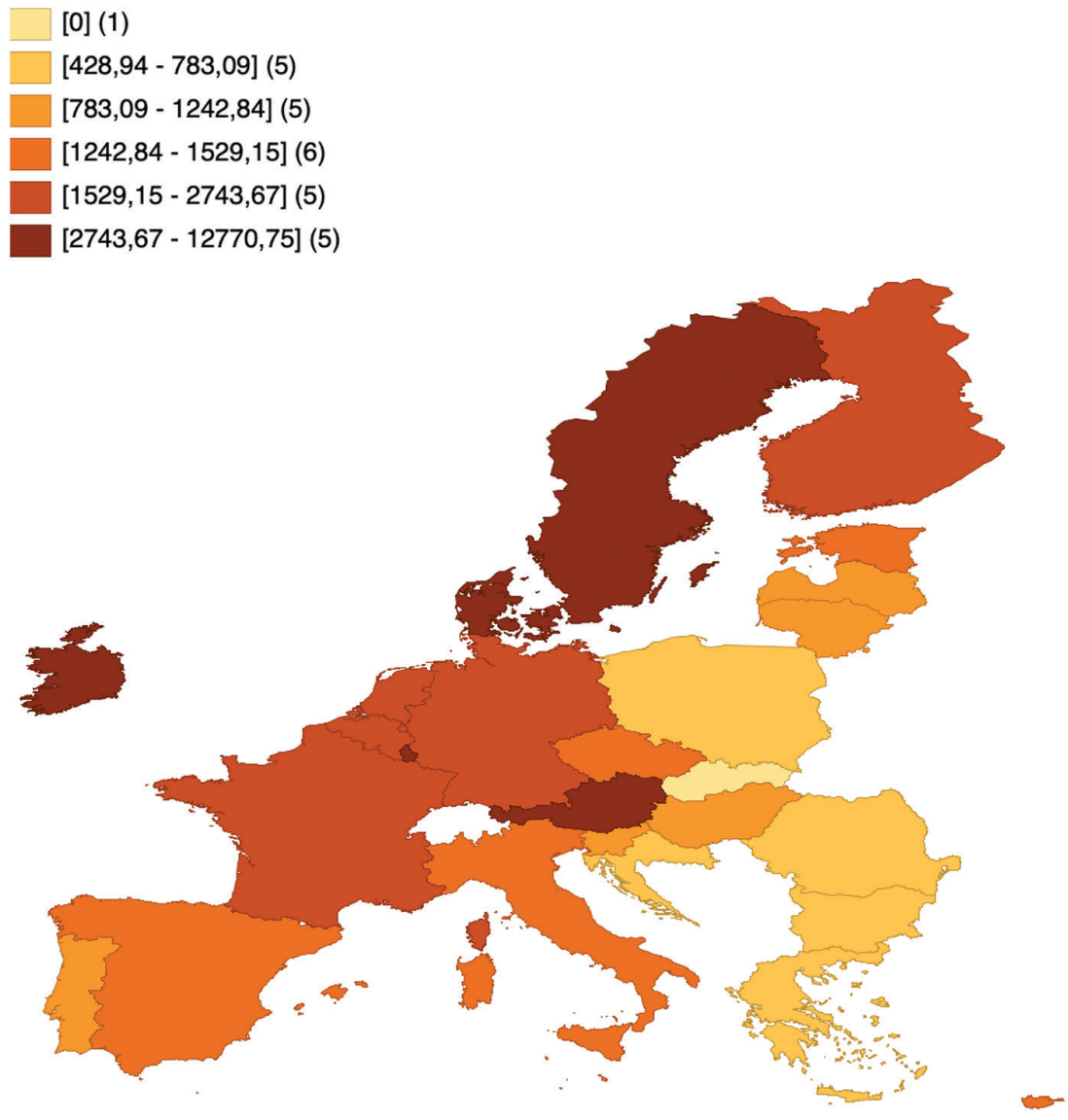

Map 2.3a Gross fixed capital formation in the second quarters of 2019 in the member states of the European Union (in EUR, constant prices from Q2 of 2020). Source: own calculation based on https://ec.europa.eu/eurostat/ data/database.

\subsection{Exports of goods and services}

Figure 2.6 represents the dynamics of changes in the proportion of exports of goods and services in GDP. The proportion of exports in GDP rose by $0.9 \%$ p.a. on average in 2006-2008 (Q1). The value of exports suddenly collapsed in Q3 of 2008 for the subsequent three quarters (by more than 5 percentage points) due to a severe downturn in international trade caused by the loss of trust in the global financial system. The proportion of exports in GDP in the European Union fell to the lowest value of $35.6 \%$ in the second quarter of 2009. Thereafter, the proportion of exports began to rise and was free from significant fluctuations until the outbreak of the pandemic. The value of 

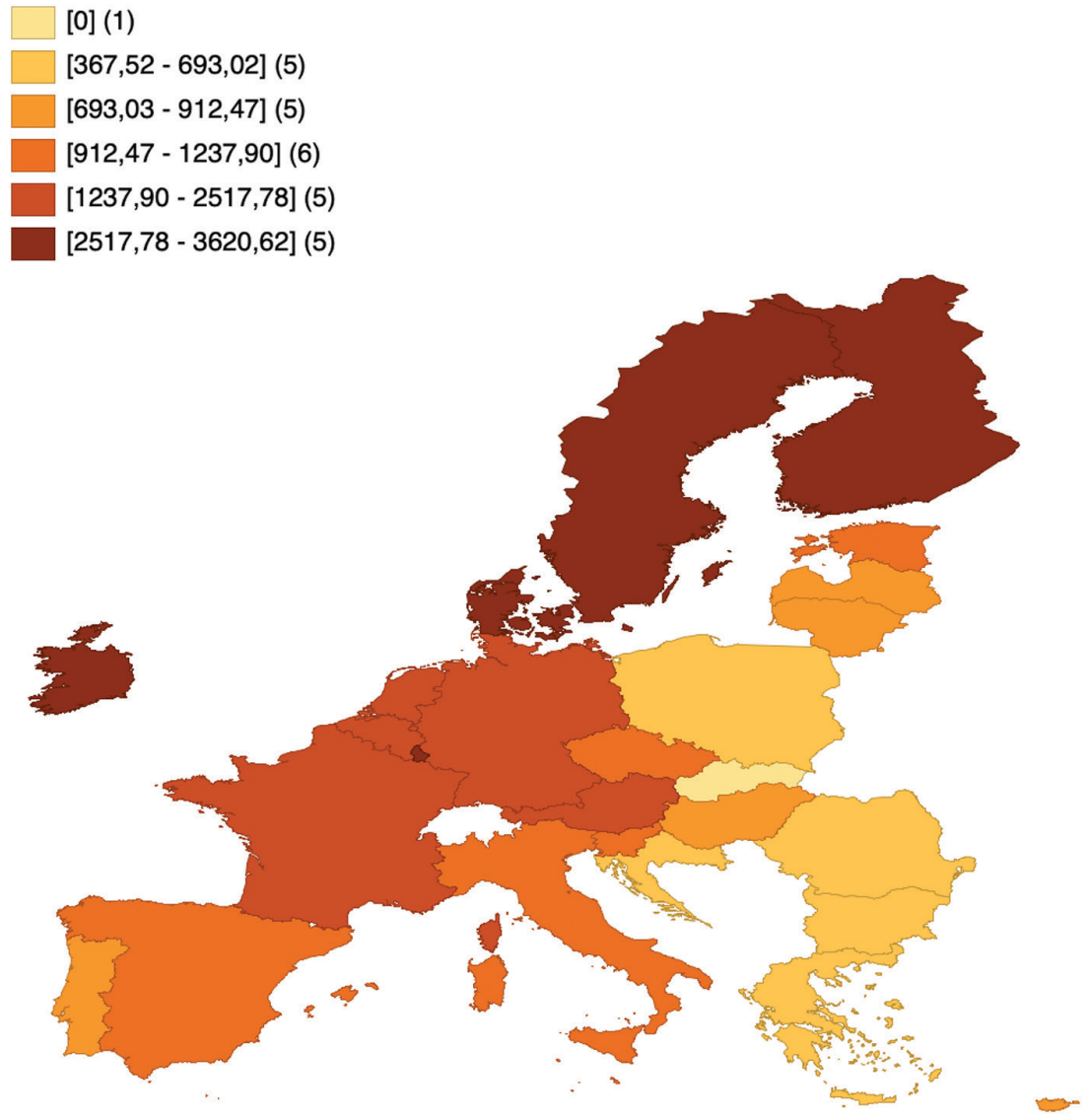

Map 2.3b Gross fixed capital formation in the second quarters of 2020 in the member states of the European Union (in EUR, constant prices from Q2 of 2020). Source: own calculation based on https://ec.europa.eu/eurostat/ data/database.

exports of goods and services dramatically fell between the first and second quarter of 2020 - by more than 5 percentage points. The average annual rate of increase in the value of exports between the second quarter of 2009 (the lowest value of exports) and the first quarter of 2020 amounted to $0.72 \%$.

An analysis of differences and similarities shown on the Figure 2.7 in the volumes of exports per capita in the EU member states leads to the following generalizations. The strongest similarities in the values of the discussed variable were characteristic of 8 pairs of states: Malta and the Netherlands, Greece and Croatia, Poland and Portugal, Spain and Italy, France and Lithuania, the Czech Republic and Slovenia, Estonia and Finland, and Denmark and Austria. Luxembourg is characterized by a value of exports 
36 Monika Bolińska et al.

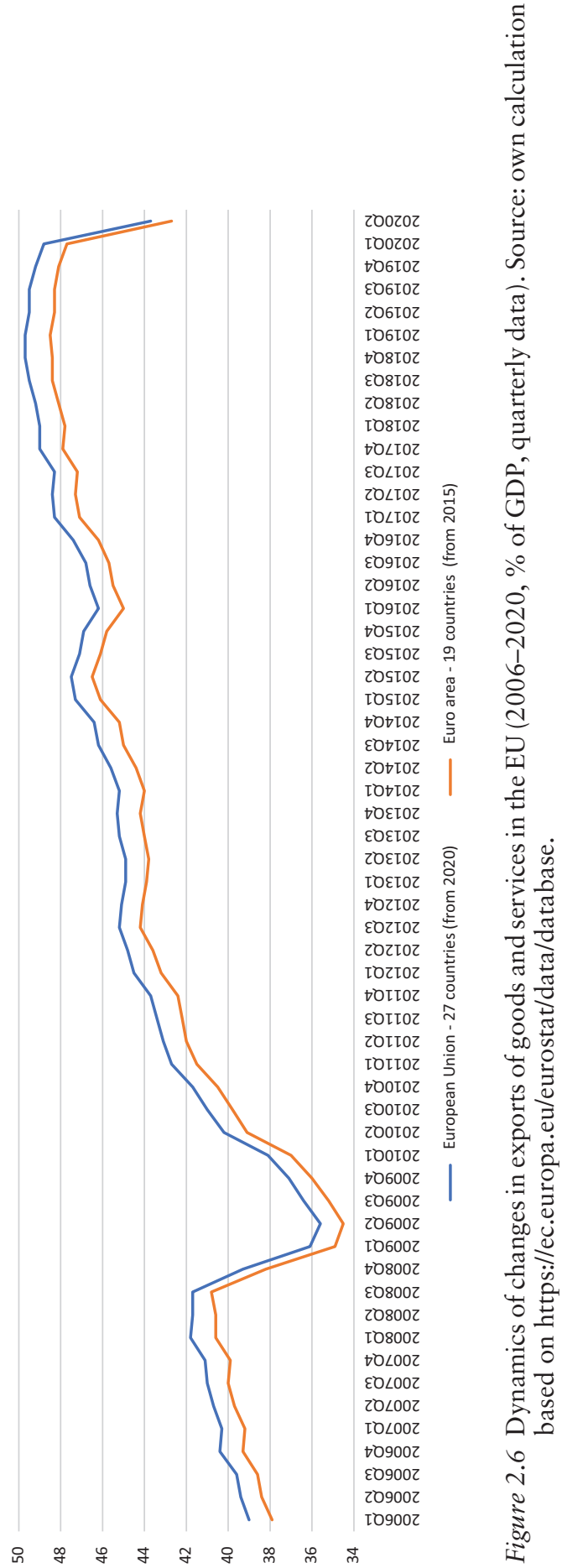




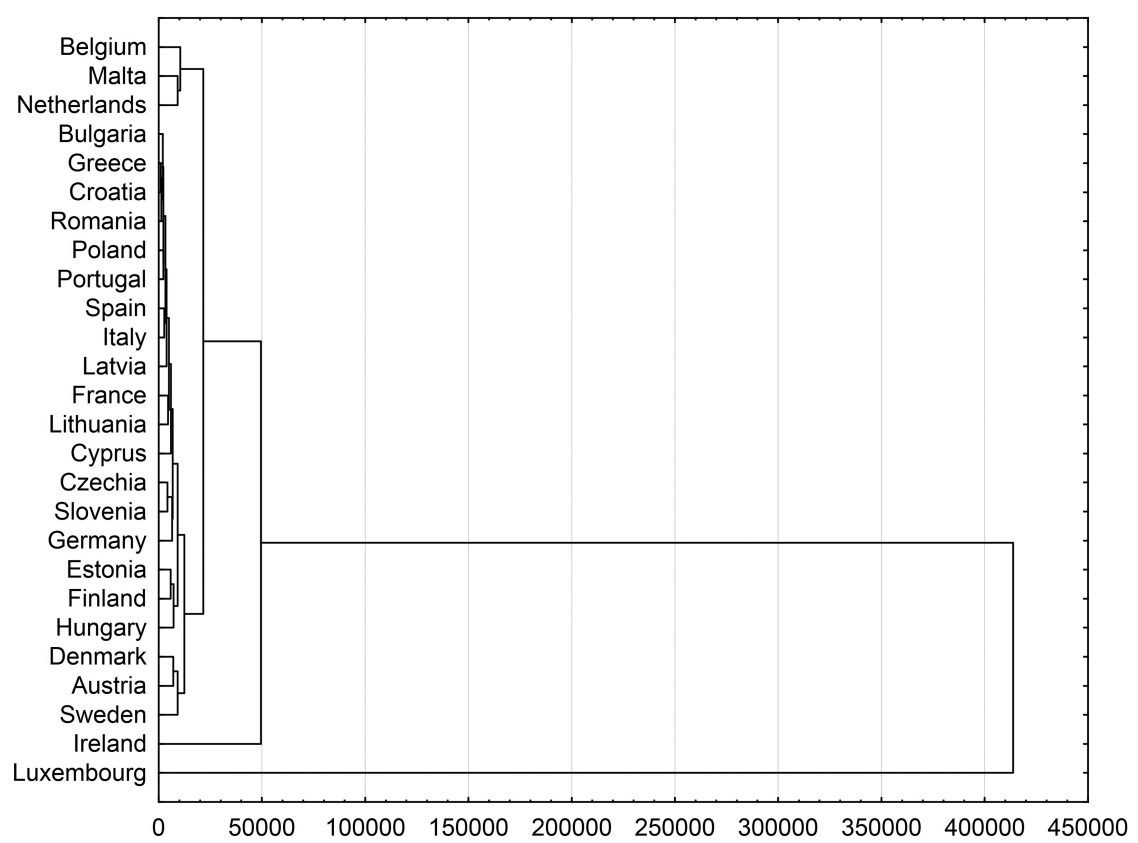

Figure 2.7 A dendrogram of similarities in exports (2006-2020, Euclidean distance). Source: own calculation based on https://ec.europa.eu/eurostat/data/ database.

per capita significantly exceeding those achieved by the other states, and as such clearly stands out. In the clustering tree, similarity clusters can also be distinguished. The first cluster includes Denmark, Austria and Sweden, countries that achieved an average value of exports per capita of about EUR 8,000. Another cluster is formed by Estonia, Finland and Hungary with an average value of exports of goods and services amounting in the analyzed period to about EUR 5,000. The third cluster includes the Czech Republic, Slovenia and Germany; the fourth Belgium, Malta and the Netherlands, which achieved high average values of per-capita exports (excluding the outstanding economies of Luxembourg and Ireland). The last and largest cluster includes Bulgaria, Greece, Croatia, Romania, Poland and Portugal.

The states classified in the largest cluster were characterized in the analyzed period by the lowest average values of exports per capita. The lowest values of the analyzed variable, not exceeding EUR 2,000 per capita, were recorded in Bulgaria (EUR 1,348.55), Romania (EUR 1,441.82), Greece (EUR 1,555.14), Croatia (EUR 1,639.16) and Poland (EUR 1,861.38); those countries also recorded, in the first two quarters of 2020, the slightest falls of exports resulting from the restrictions imposed by governments and aimed to control the spread of the SARS-CoV-2. 


\section{Monika Bolińska et al.}

The highest values of exports per capita (exceeding EUR 10,000) were recorded in the Benelux countries: Belgium (EUR 11,644.97), the Netherlands (EUR 11,723.06) and Luxembourg (EUR 67,531.70); also in Malta (EUR 11,033.99) and Ireland (EUR 15,077.92).

Maps 2.4(a) and 2.4(b) represent the spatial differentiation of exports of goods and services in the 26 European economies in the second quarter of 2019 and in the second quarter of 2020. 15 states changed their positions in the general ranking of quintile groups; seven of them rose and eight fell in the ranking. The group of countries that achieved rises: Poland, by three positions; Bulgaria, by two positions; Cyprus, Estonia, Germany, Latvia and Malta by one position. Poland was the only country to change its quintile group from that with the lowest values into that characterized by low
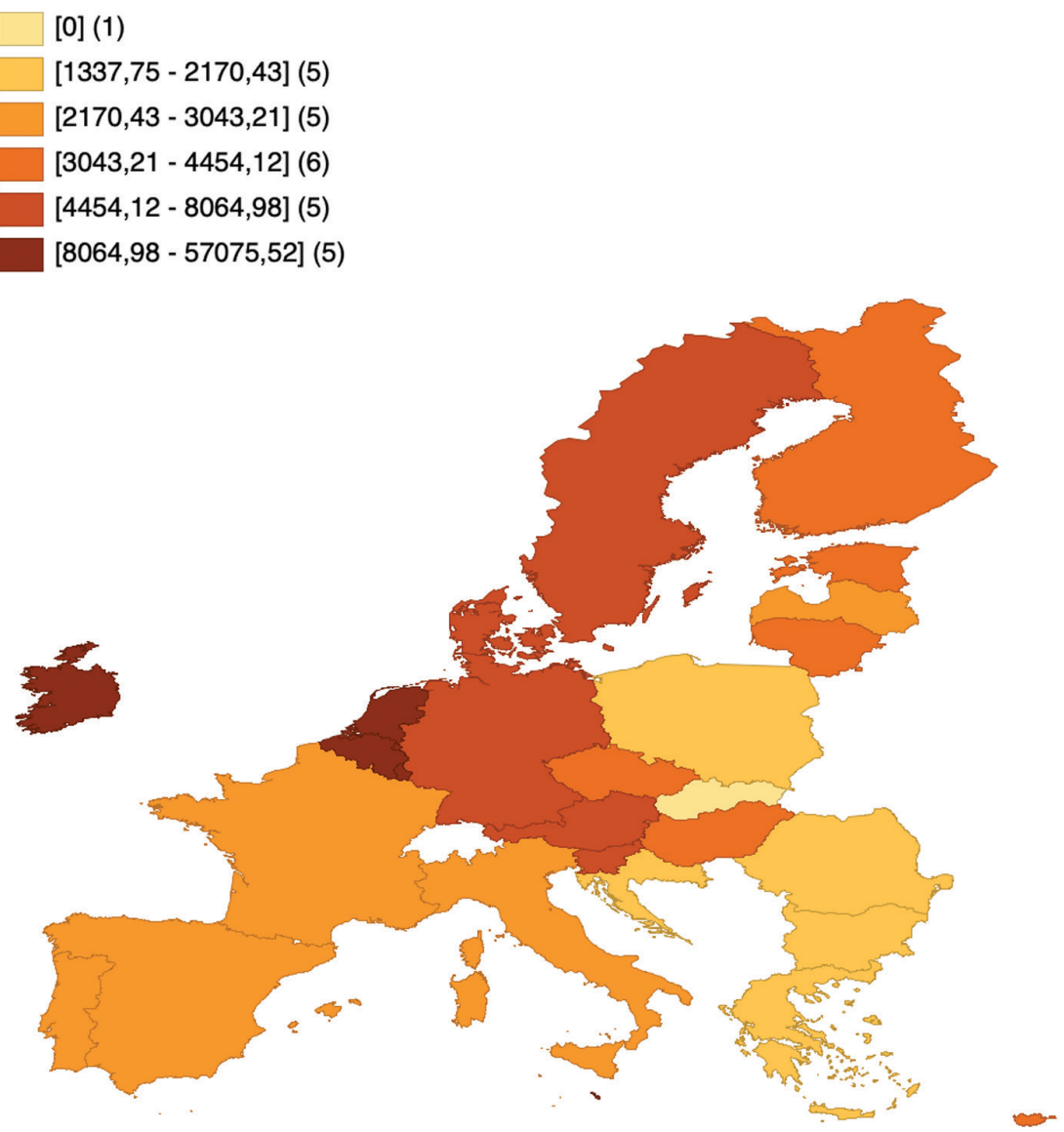

Map 2.4a Exports per capita in the second quarters of 2019 in the member states of the European Union (in EUR, constant prices from Q2 of 2020). Source: own calculation based on https://ec.europa.eu/eurostat/data/database. 
values. Croatia and the Czech Republic fell in the ranking by two positions while France, Italy, the Netherlands, Portugal, Slovenia and Spain fell by one position. Also, Portugal changed its quintile group.

All member states of the European Union recorded reductions in exports of goods and services in the second quarter of 2020 compared to the corresponding period in 2019 due to the imposed restrictions. The greatest decrease in exports was recorded in Luxembourg (by EUR 5,281.44 per capita between Q2 of 2019 and Q2 of 2020). A significant fall also affected the other Benelux countries: the Netherlands (by EUR 2,403.19) and Belgium (by EUR 1,803.15). The value of exports also significantly dropped (by EUR 1,942.67) in Malta, with foreign trade and financial services as its main economic sectors. Only a few among the EU economies recorded
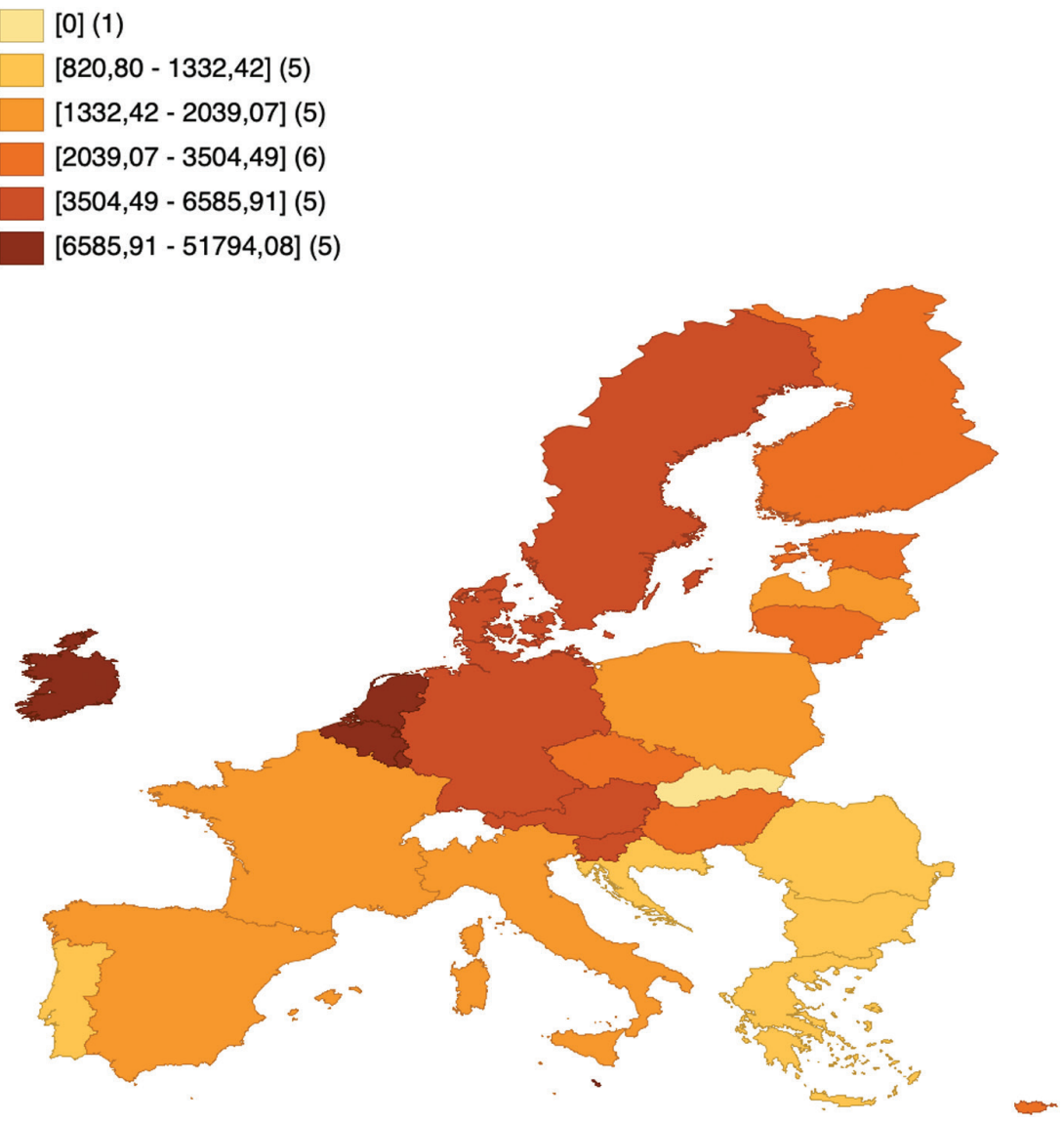

Map 2.4b Exports per capita in the second quarters of 2020 in the member states of the European Union (in EUR, constant prices from Q2 of 2020). Source: own calculation based on https://ec.europa.eu/eurostat/data/database. 
slight decreases in exports: Latvia (by EUR 574.10), Poland (EUR 544.42), Romania (EUR 516.95) and Bulgaria (EUR 461.23).

\subsection{Imports of goods and services}

Figure 2.8 represents the dynamics of changes in the proportion of imports of goods and services in GDP. The proportion of imports in GDP rose by $0.8 \%$ per annum on average between 2006 and Q3 of 2008. The variable sharply dropped thereafter (by 6.4 percentage points over the three subsequent quarters). The value of imports and its proportion in GDP continually grew since $\mathrm{H} 2$ of 2009 . The proportion amounted to $46.6 \%$ in the second quarter of 2019. The average annual rate of growth in the discussed period amounted to $0.8 \%$. The second quarter of 2020 saw a severe reduction in the value of imports in the EU economy ( 5 percentage points compared to the corresponding quarter of 2019).

An analysis of differences and similarities in the volumes of imports per capita in the EU member states leads to the following generalizations. The strongest similarities in imports were observed between the following pairs of countries: Malta and the Netherlands, Greece and Romania, Spain and Italy, the Czech Republic and Germany, Latvia and Lithuania, Denmark and Austria, and Estonia and Hungary. In the dendrogram depicted in Figure 2.9, two smaller and two larger clusters of similarities can be distinguished. The first of the smaller clusters is formed by Belgium, Malta and the Netherlands. The second includes Denmark, Austria and Sweden, with an average value of imports of about EUR 7,000. A larger cluster is formed by Bulgaria, Greece, Romania, Croatia, Poland, Spain, Italy and Portugal. Another larger cluster includes the Czech Republic, Germany, Slovenia, Cyprus, Finland, Latvia and Lithuania, with an average value of imports in the years 2006-2020 amounting to about EUR 4,000 per capita.

The largest average values of imports per capita were recorded in the years 2006-2020 in Luxembourg (EUR 55,866.08), Ireland (EUR 12,648.66), Belgium (EUR 11,413.74), Malta (EUR 10,639.52), and the Netherlands (EUR 10,311.61). The lowest values of imports of goods and services were recorded in the same states that achieved the lowest values of exports. The lowest average values were recorded in the years 2006-2020 in Bulgaria (EUR 1,470.65), Romania (EUR 1,768.95), Croatia (EUR 1,797.33), Poland (EUR 1,851.14) and Greece (EUR 1,940.68); those economies also recorded the slightest decrease in imports, resulting from the restrictions imposed to control the spread of the SARS-CoV-2.

Maps 2.5(a) and 2.5(b) represent the spatial differentiation of imports of goods and services in the 26 European economies - in the second quarter of 2019 and in the second quarter of 2020. Eight economies changed their positions in the general ranking between the analyzed periods. Cyprus rose by three positions, and Slovenia fell by three positions, so that the two countries "swapped" their groups. Bulgaria, Malta and Poland each rose in the 


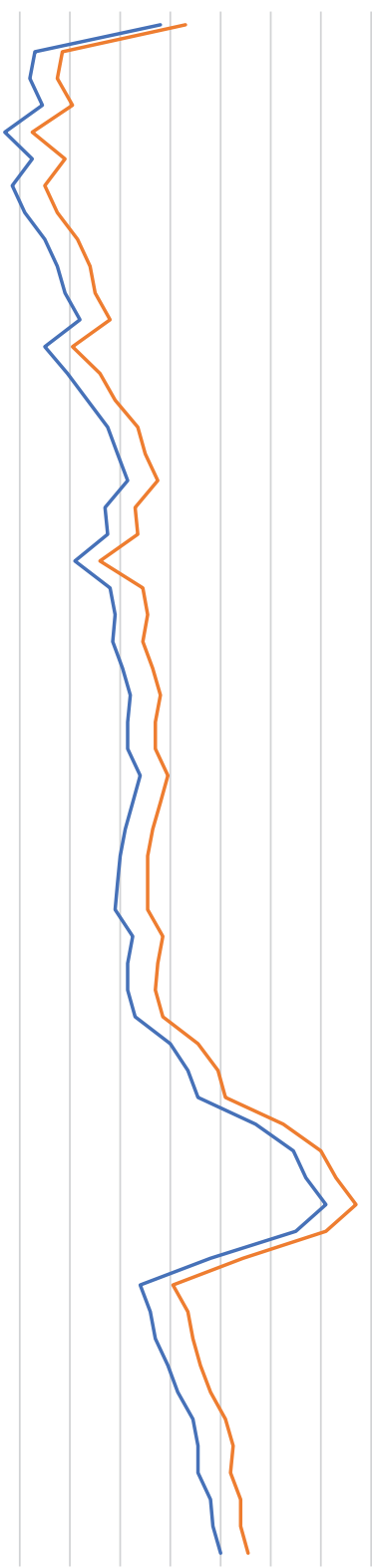

roozor

IOOZOZ

tO6LOZ

घO6t0Z

ZO6T0Z

I06โ0Z

tO8L0Z

عO8T0Z

rostoz

IO8T0Z

†OLIOZ

$\varepsilon O \angle T O Z$

ZO $\angle$ TOZ

IOLTOZ

$\mathrm{O}$ OI0Z

عO9T0Z

rogt0z

IO9LOZ

tOSTOZ

عOSTOZ

rostor

IOSTOZ

tOtIOZ

हOtTOZ

rOtTOZ

IOtTOZ

†OETOZ

हDETOZ

ZOETOZ

toetoz

tOZTOZ

EOZLOZ

IOZTOZ

tOItOZ

EOLTOZ

zottoz

IOITOZ

tDotoz

EOOLOZ

rootor

IOOTOZ

t06002

EO6002

z06002

IO6002

tO8002

EO8002

Z08002

IO800Z

tOLOOZ

$\varepsilon O \angle 00 Z$

ZOLO0Z

IO $\angle 00 Z$

t09002

EO900Z

zO9002

I09002

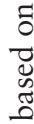

롱

营

u

3

ij

ڤ

莡

군

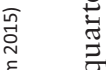

인

ڤ

ठ

7 वे

ปัฐ

1

ลัก

올

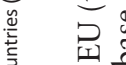

요

ก

ㅇ. .

ร

尝

芯芯

$\Xi$

\&

ఉ్ర 


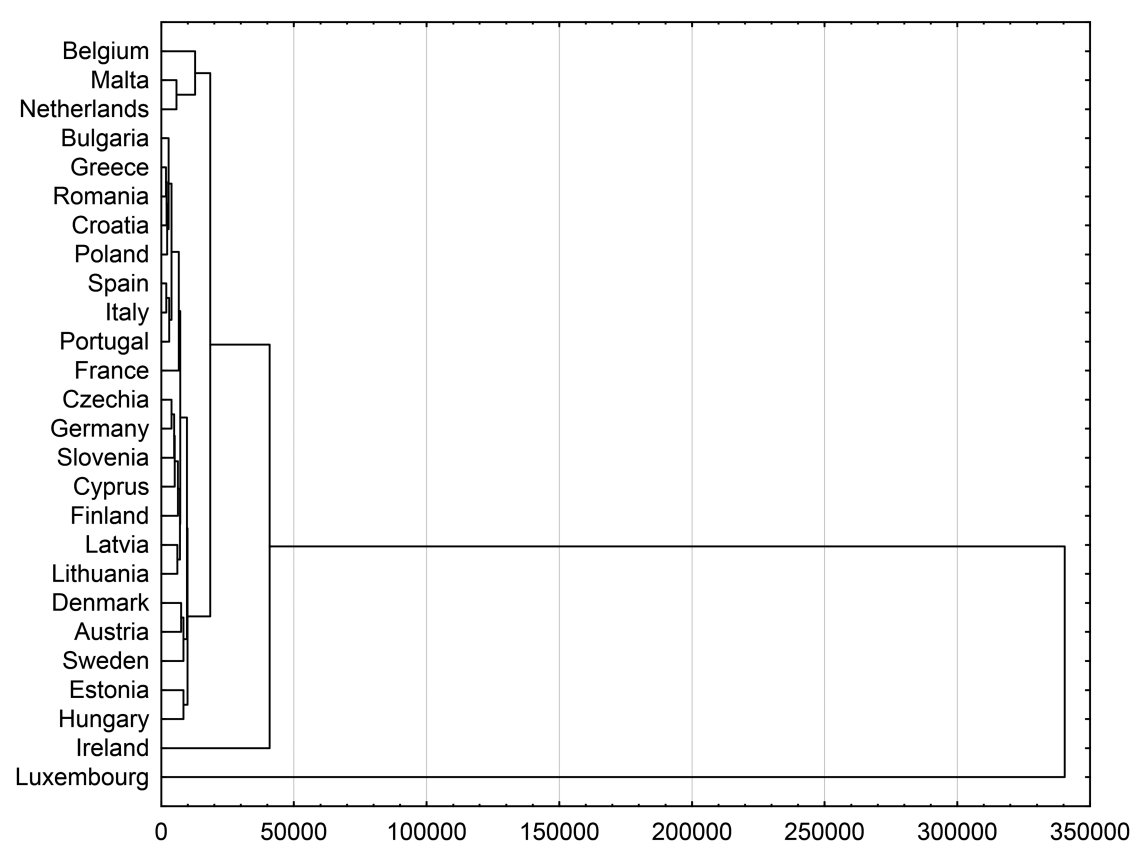

Figure 2.9 A dendrogram of similarities in imports (the years 2006-2020, Euclidean distance). Source: own calculation based on https://ec.europa.eu/eurostat/ data/database.

general ranking by one position. A drop in the ranking of imports of goods and services in the EU states was recorded in the case of the Netherlands, Romania and Spain (by one position). Spain was reclassified from the group characterized by low values to the group with the lowest values of imports of goods and services per capita and was replaced by Poland.

All member states of the European Union recorded reductions in imports of goods and services in the second quarter of 2020 compared to the corresponding period in 2019 due to the imposed restrictions. The sharpest decreases affected Ireland (by EUR 10,278.69 per capita), Luxembourg (EUR 5,425.82), the Netherlands (EUR 2,152.84) and Belgium (EUR 2,076.84). The group of states that recorded the slightest decreases in imports includes Croatia (EUR 578.74), Greece (EUR 521.06), Romania (EUR 509.50) and Bulgaria (EUR 462.43).

\subsection{Conclusions}

An analysis of the impact of the COVID-19 pandemic on the differentiation of selected macroeconomic variables characterizing the EU economies over a short period leads to the following generalizations. 
[0] (1)

$[1433,74-1978,65](5)$

$[1978,65 .-3131,26](5)$

$[3131,26-4522,59](6)$

$[4522,59-6946,23](5)$

$[6946,23-47048,19](5)$

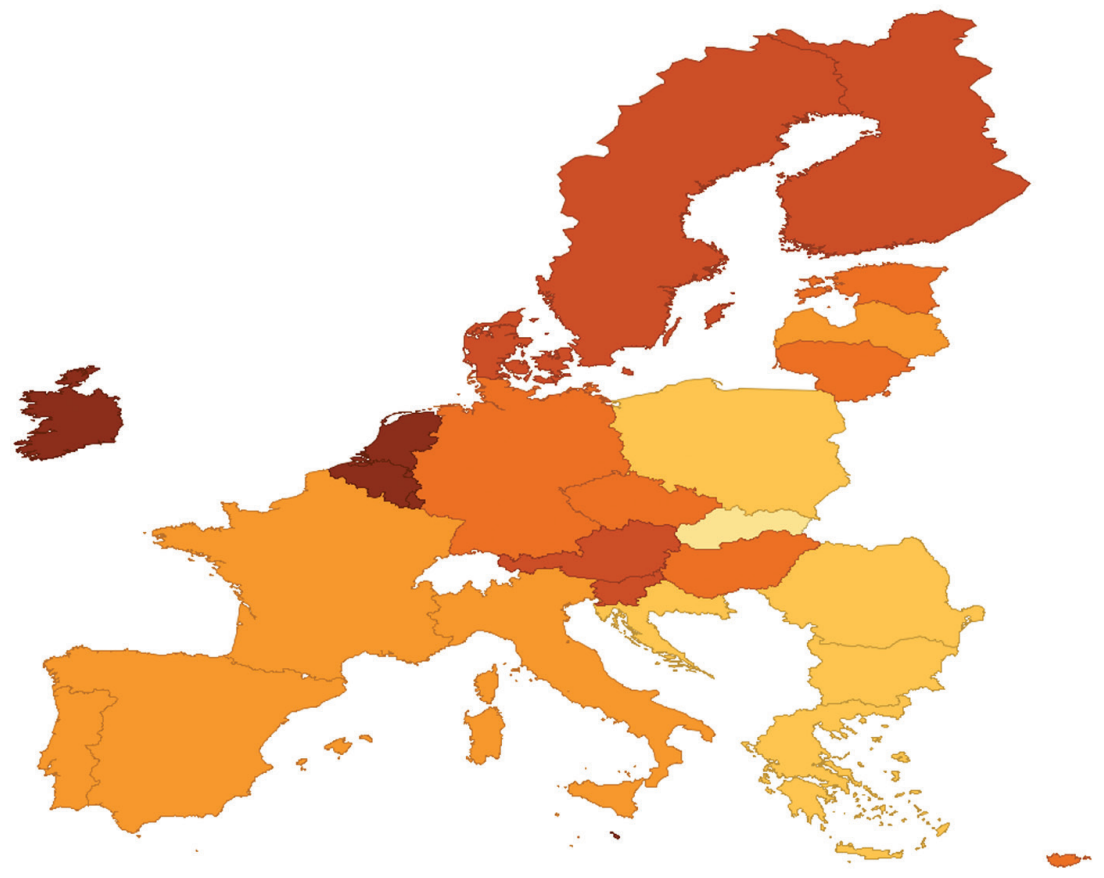

Map 2.5a Imports per capita in the second quarters of 2019 in the member states of the European Union (in EUR, constant prices from Q2 of 2020). Source: own calculation based on https://ec.europa.eu/eurostat/data/database.

First, the sharpest decrease in the absolute value of GDP per capita between Q2 of 2019 and Q2 of 2020 was recorded in the countries that in the years 2006-2019 belonged to the group with medium, high and highest values of average citizen's wealth. The depth of decreases in GDP (and consequently GDP per capita) in the second quarter of 2020 was unprecedented in the post-war history of the member states of the former European Communities and the current European Union.

Second, this variety of responses of labor markets to the supply and demand shock in Q2 of 2020 can be interpreted from various perspectives. The causes of such diversity should be sought in the varying scenarios of the implementation of lockdown measures. 

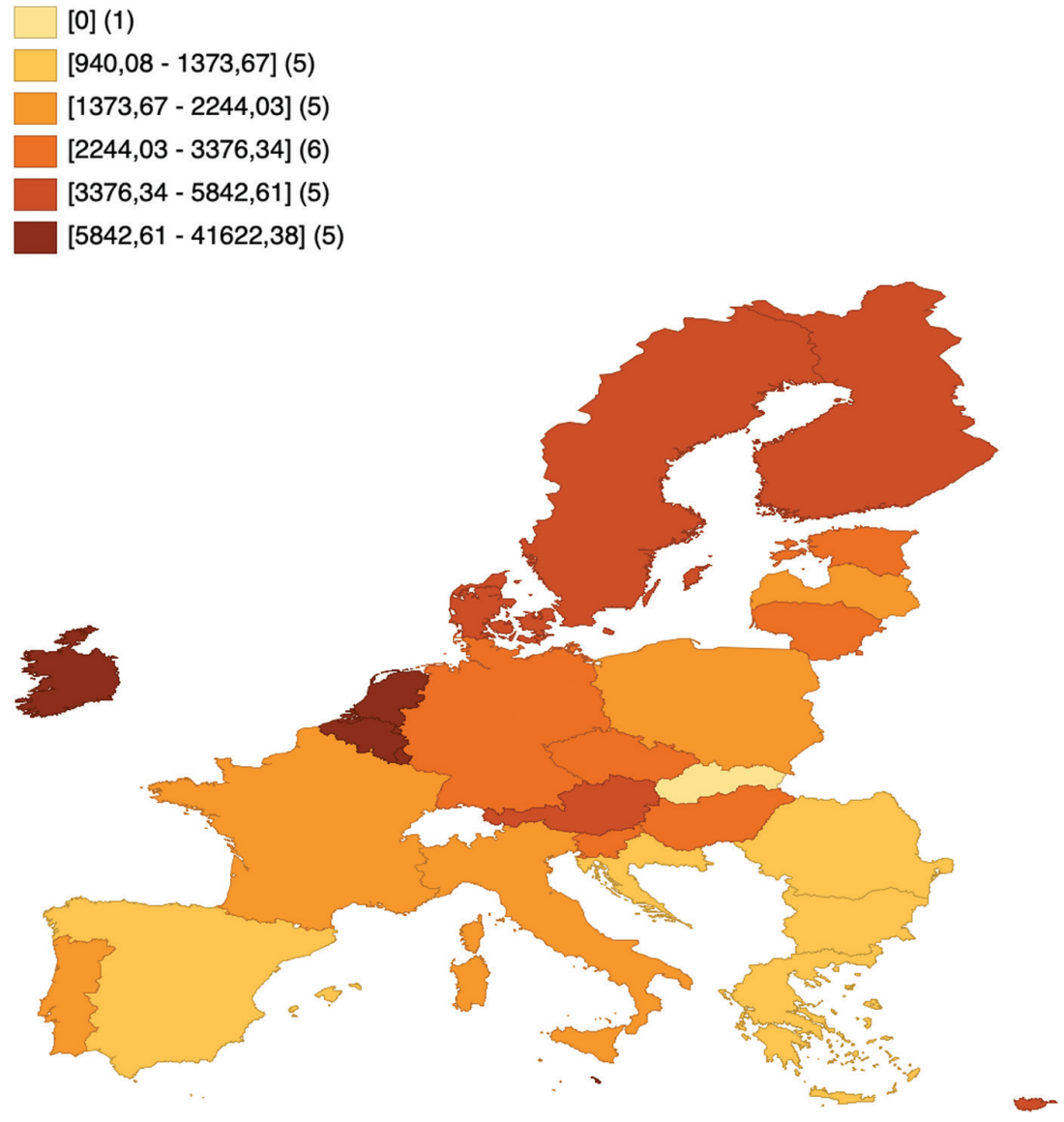

Map 2.5b Imports per capita in the second quarters of 2020 in the member states of the European Union (in EUR, constant prices from Q2 of 2020) Source: own calculation based on https://ec.europa.eu/eurostat/data/database.

Third, all analyzed EU economies recorded a clear reduction in the percapita expenditures on property and plant equipment bought or produced. The highest absolute values of decrease were characteristic of Ireland, Luxembourg, Cyprus, Belgium and France. The slightest decrease affected Denmark, Romania, Portugal, Bulgaria and Greece.

Fourth, all member states of the EU recorded a sharp decrease in both exports and imports of goods and services in the second quarter of 2020 compared to the corresponding period in 2019 due to the imposed restrictions. 


\section{References}

Atkeson, A. (2020). What will be the economic impact of COVID-19 in the US? Rough estimates of disease scenarios. NBER Working Paper, No. 26867. http:// www.nber.org/papers/w26867 (accessed December 15, 2020).

Baumeister, Ch., Guérin, P. (2020). A comparison of monthly global indicators for forecasting growth. NBER Working Paper, No. 28014. http://www.nber.org/ papers/w28014 (accessed December 15, 2020).

Brock, W., Xepapadeas, A. (2020). The economy, climate change and infectious diseases: Links and policy implications. Environmental and Resource Economics, 76, 811-824. https://doi.org/10.1007/s10640-020-00442-z (accessed December $15,2020)$.

Dieppe, A. (2020). Global productivity: Trends, drivers, and policies. Advance Edition. Washington, DC: World Bank.

Forsythe, E., Kahn, L.B., Lange, F., Wiczer, D.G. (2020). Searching, recalls, and tightness: An interim report on the Covid labor market. NBER Working Paper, No. 28083. http://www.nber.org/papers/w28083 (accessed January 02, 2020).

IMF - International Monetary Fund (2020). World economic outlook: A long and difficult ascent. Washington, DC: International Monetary Fund.

IMF (2020). World economic outlook. April 2020: The Great Lockdown. https:// www.imf.org/en/Publications/WEO/Issues/2020/04/14/weo-april-2020 (accessed December 15, 2020).

Lik Ng, W. (2020). To lockdown? When to peak? Will there be an end? A macroeconomic analysis on COVID-19 epidemic in the United States. Journal of Macroeconomics, 65, 103230.

Ludvigson, S.C., Ma, S., Ng, S. (2020). COVID-19 and the macroeconomic effects of costly disasters. NBER Working Paper No. 26987. https://www.nber.org/ papers/w27784 (accessed December 15, 2020).

OECD (2020). OECD economic outlook, volume 2020, issue 2: Preliminary version. Paris: OECD Publishing. https://doi.org/10.1787/39a88ab1-en (accessed December 15, 2020). 